\title{
Emerging therapies in the management of macular edema: a
}

\section{review [version 1; peer review: 2 approved]}

\author{
Riccardo Sacconi, Chiara Giuffrè, Eleonora Corbelli, Enrico Borrelli, \\ Giuseppe Querques, Francesco Bandello
}

Department of Ophthalmology, University Vita-Salute, IRCCS Ospedale San Raffaele, Via Olgettina 60, Milan, 20132, Italy

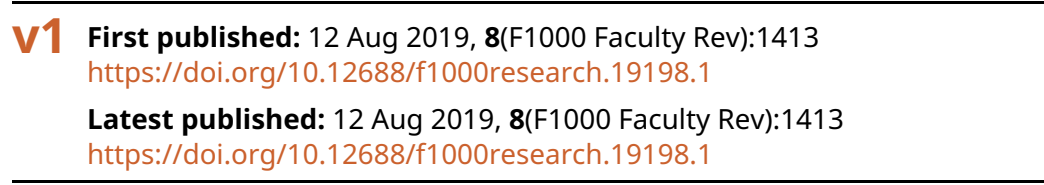

\section{Abstract}

Macular edema (ME) is a major complication of several vascular and inflammatory retinal diseases. Multiple mechanisms are implicated in its development and lead to visual impairment that could be reversible (the acute stages) or not reversible (long-standing ME). For this reason, an effective approach to the treatment of ME is of paramount importance in order to prevent irreversible damage of visual function. In this review, we discuss the management of ME and, in particular, current data of studies and clinical trials about drugs that have already been evaluated or are under investigation in the management of ME. Although several diseases could lead to the development of ME, we focus on the three main causes: diabetic retinopathy (DR), retinal vein occlusion (RVO), and uveitis. The introduction into clinical practice of anti-vascular endothelial growth factor injections (ranibizumab and aflibercept) and dexamethasone implants has revolutionized the treatment of ME secondary to DR and RVO. However, new drugs are needed in the treatment of resistant forms of ME secondary to DR and RVO. A fluocinolone acetonide implant has been approved by the US Food and Drug Administration for the treatment of diabetic ME but not for RVO. Furthermore, brolucizumab and abicipar pegol have been shown to be effective in preliminary studies and have the chance to be approved soon for diabetic ME treatment. In ME secondary to uveitis, a crucial role is played by corticosteroids and non-biologic immunomodulatory drugs. However, several new biologic agents are under investigation in different clinical trials and could be important new therapeutic options in cases with a low response to first-line therapy. However, only a few of these drugs will enter the market after proving their safety and efficacy. Only after that will we be able to offer a new therapeutic option to patients affected by uveitic ME.

\section{Keywords}

corticosteroid, diabetic macular edema, macular edema, retinal vein occlusion, uveitic macular edema, uveitis, vascular endothelial growth factor

\section{Open Peer Review}

Approval Status

1 2

version 1

12 Aug 2019

Faculty Reviews are review articles written by the prestigious Members of Faculty Opinions. The articles are commissioned and peer reviewed before publication to ensure that the final, published version is comprehensive and accessible. The reviewers who approved the final version are listed with their names and affiliations.

1. Andrew A. Chang, Sydney Institute of Vision Science, Sydney, Australia University of Sydney, Sydney, Australia

2. Akitaka Tsujikawa, Kyoto University Graduate School of Medicine, Kyoto, Japan Any comments on the article can be found at the end of the article. 
Corresponding author: Francesco Bandello (bandello.francesco@hsr.it)

Author roles: Sacconi R: Conceptualization, Data Curation, Methodology, Resources, Writing - Original Draft Preparation, Writing Review \& Editing; Giuffrè C: Conceptualization, Data Curation, Methodology, Writing - Original Draft Preparation; Corbelli E:

Conceptualization, Data Curation, Methodology, Writing - Original Draft Preparation; Borrelli E: Data Curation, Methodology, Resources, Validation, Writing - Review \& Editing; Querques G: Conceptualization, Methodology, Resources, Validation, Writing - Review \& Editing; Bandello F: Conceptualization, Methodology, Resources, Writing - Review \& Editing

Competing interests: GQ is a consultant for Alimera Sciences, Allergan Inc., Amgen (Thousand Oaks, CA, USA), Bayer Schering-Pharma (Berlin, Germany), Heidelberg (Germany), KBH (Chengdu; China), LEH Pharma (London, UK), LumiThera (Poulsbo, WA, USA), Novartis (Basel, Switzerland), Sandoz (Berlin, Germany), Sifi (Catania, Italy), Sooft-Fidea (Abano, Italy), and Zeiss (Dublin, OH, USA). FB is a consultant for Alcon (Fort Worth, TX, USA), Alimera Sciences, Allergan Inc., Farmila-Thea (Clermont-Ferrand, France), Bayer ScheringPharma, Bausch + Lomb, Genentech, Hoffmann-La Roche (Basel, Switzerland), Novagali Pharma (Évry, France), Novartis, Sanofi-Aventis (Paris, France), Thrombogenics (Heverlee, Belgium), and Zeiss. The other authors declare that they have no competing interests.

Grant information: The author(s) declared that no grants were involved in supporting this work.

Copyright: ( 2019 Sacconi R et al. This is an open access article distributed under the terms of the Creative Commons Attribution License, which permits unrestricted use, distribution, and reproduction in any medium, provided the original work is properly cited.

How to cite this article: Sacconi R, Giuffrè C, Corbelli E et al. Emerging therapies in the management of macular edema: a review [version 1; peer review: 2 approved] F1000Research 2019, 8(F1000 Faculty Rev):1413 https://doi.org/10.12688/f1000research.19198.1

First published: 12 Aug 2019, 8(F1000 Faculty Rev):1413 https://doi.org/10.12688/f1000research.19198.1 


\section{Introduction}

Macular edema (ME) is the major cause of visual impairment in several metabolic, vascular, and inflammatory retinal diseases. It affects about 7 million patients with diabetic retinopathy (DR) ${ }^{1}$ and 3 million patients with retinal vein occlusion $(\mathrm{RVO})^{2}$ and causes a visual decline in $40 \%$ of patients affected by uveitis ${ }^{3}$. ME is characterized by an abnormal presence of fluid inside the retinal layers of the macula ${ }^{4}$. Normally, there is a fine balance between fluid that enters and exits inside the retinal layers. This balance is necessary for the retinal homeostasis in order to obtain the tissue transparency. However, for several diseases, this balance could be compromised, resulting in an imbalance between fluid that enters and exits and thus causing ME development. The accumulation of the fluid could be extracellular (resulting in cystic space formation), intracellular (causing a swelling of the cells), or subretinal (causing the accumulation in the subretinal space $)^{4-6}$. The regulation of fluid and molecules that enter and exit from the vitreous, retinal vessels, and choroidal vessels is controlled by structures forming the inner and the outer blood-retinal barriers ${ }^{7,8}$. The inner blood-retinal barrier is composed of the tight junctions between the endothelial cells of the capillaries inside the retinal plexuses, astrocytes, Müller cells, pericytes, and smooth muscle cells $^{9-11}$. On the other hand, the outer blood-retinal barrier is composed of the retinal pigment epithelium (RPE) cells and their inter-cellular junctions that regulate the passage of fluid and molecules from the choroidal vessels to the neurosensory retina ${ }^{12}$.

ME causes visual impairment that could be reversible or permanent. Multiple mechanisms are implicated in the development of visual impairment due to ME. During the acute phase of ME development, the imbalance of fluid that enters and exits inside the retinal layers causes a retinal hydration state that interferes with the passage of light through the neuroretinal layers. These alterations lead to an acute effect on visual function, such as central vision loss, a relative central scotoma, metamorphopsia, impaired stereopsis, or disturbed color vision ${ }^{13,14}$. In this phase, the treatment or the spontaneous resolution of ME is able to reverse the visual impairment. On the other hand, long-standing ME causes irreversible changes of the retinal layers, leading to a permanent deficit in visual function. The main anatomical damage caused by chronic $\mathrm{ME}$ is linked to alterations of the outer limiting membrane, photoreceptor segments (outer nuclear layer thinning and outer segment atrophy), and disorganization of inner retinal layers ${ }^{15-17}$. For these reasons, the treatment of ME should be performed as soon as possible in order to avoid structural retinal changes and irreversible damage of visual function.

In this review, we focus on the management of $\mathrm{ME}$ and, in particular, on current data of studies and clinical trials about drugs that are under investigation or have already been evaluated in ME management. Although several diseases could lead to the development of $\mathrm{ME}$ (that is, $\mathrm{DR}^{1}, \mathrm{RVO}^{2}$, uveitis ${ }^{3}$, IrvineGass postoperative $\mathrm{ME}^{18}$, idiopathic macular telangiectasia type 1 and $2^{19,20}$, perifoveal exudative vascular anomalous complex ${ }^{21}$, paclitaxel-induced maculopathy ${ }^{22}$, MEK inhibitor-associated maculopathy ${ }^{23}$, hypoproteinemia ${ }^{24}$, paracentral acute middle maculopathy ${ }^{25}$, and central serous chorioretinopathy ${ }^{26}$ ), we will discuss the management of the major causes of $\mathrm{ME}$, including DR, RVO, and uveitis.

\section{Management of macular edema: diabetic retinopathy}

Diabetic macular edema (DME) is the first cause of visual loss in patients with diabetes ${ }^{27}$. For several years, grid and focal laser photocoagulation were considered the standard of care for DME. However, thanks to the introduction into clinical practice of intravitreal anti-vascular endothelial growth factor (anti-VEGF) injections and corticosteroid implants, the treatment of DME has been completely revolutionized. Anti-VEGF molecules, such as ranibizumab (Lucentis, Novartis Europharm Ltd, Horsham, UK) and aflibercept $\left(\right.$ Eylea $^{\circledR}$, Bayer Pharma, Berlin, Germany), demonstrated a benefit ratio and superior efficacy compared with the previous standard of care (laser photocoagulation) in large phase 3 clinical trials ${ }^{28-32}$. The encouraging results in terms of clinically relevant improvement of visual acuity, reduction of fluid accumulation, and decreased severity of DR led to their approval for DME treatment by the US Food and Drug Administration (FDA) starting in 2012. Owing to the efficacy and safety profile of anti-VEGF therapy, it has become the first-line treatment. Besides ranibizumab and aflibercept, bevacizumab demonstrated efficacy in the treatment of DME. Bevacizumab is a monoclonal antibody used to treat a number of types of cancer, although its intraocular use is considered off-label. The Diabetic Retinopathy Clinical Research Network (DRCR.net) evaluated the outcomes of patients with DME treated with bevacizumab, ranibizumab, or aflibercept and reported best outcomes in patients whose DME was treated with aflibercept with visual acuity of $20 / 50$ or worse at baseline ${ }^{33}$.

Ziv-aflibercept (Zaltrap; Sanofi-Aventis, Bridgewater, NJ, USA/ Regeneron Pharmaceuticals, Tarrytown, NY, USA) is a fusion protein approved by the FDA for the treatment of metastatic colorectal carcinoma. Although aflibercept and ziv-aflibercept are structurally identical, they differ for the buffer. This difference results in a higher osmolarity of ziv-aflibercept compared to aflibercept. De Andrade et al. ${ }^{34}$ tested the safety and efficacy of ziv-aflibercept in seven eyes affected by DME and disclosed no systemic or ocular complications during a 48-week follow-up. Furthermore, Mansour et $a l .{ }^{35}$ reported the off-label intraocular use of ziv-aflibercept in the treatment of 107 eyes affected by retinal diseases and concluded that ziv-aflibercept appeared safe and efficacious. However, further randomized studies are needed to demonstrate the safety and efficacy of intraocular use of ziv-aflibercept.

Corticosteroid implants are usually used as a second-line treatment for patients without significant response to anti-VEGF injections. In 2014, an intravitreal implant with $700 \mu \mathrm{g}$ of sustained-release biodegradable dexamethasone $\left(\right.$ Ozurdex $^{\circledR}$, Allergan, Inc., Irvine, CA, USA) was approved by the FDA for the treatment of DME. The MEAD study demonstrated the efficacy of dexamethasone implant in the treatment of DME with an acceptable safety profile and a low number of implants (four or five injections over a 3-year follow-up) ${ }^{36}$. 
Despite the strong efficacy achieved with anti-VEGF and corticosteroid therapies, a significant proportion of patients do not experience clinically meaningful improvements in vision in the real world with persistent or resistant forms of $\mathrm{DME}^{37-39}$. Moreover, frequent intravitreal administration is required to achieve and, in some cases, to maintain the observed early benefits of DME treatment over a long period of time, imposing a significant burden on patients, caregivers, treating physicians, and the health-care system. Both of these factors formed the impetus for developing new drugs and alternative methods of administration for the treatment of DME.

Novel treatment strategies for DME could be classified into four subgroups: a new slow-release sustained-delivery system for intraocular steroid, next-generation anti-VEGF-A drugs, combination drugs, and suprachoroidal corticosteroids.

New slow-release sustained-delivery system for intraocular steroid

Iluvien. Iluvien (Alimera Sciences, Alpharetta, GA, USA) is an injectable non-biodegradable intravitreal insert for sustained release of fluocinolone acetonide (FAc), a potent glucocorticoid receptor agonist, for up to 36 months. The implant, inserted into the vitreous cavity via a 25 -gauge needle, contains $0.19 \mathrm{mg}$ of FAc and provides a release rate of $0.2 \mu \mathrm{g} /$ day. Iluvien is usually used for the treatment of DME in patients who previously received a course of corticosteroids and did not have a significant increase in eye pressure. The clinical efficacy of Iluvien has been evaluated in a phase 3 FAME clinical trial and confirmed by several real-life reports ${ }^{40-42}$. Of note, the continuous dosing ensures the treatment even in the case of delay to follow-up appointments. This is a fundamental advantage given that many factors can change the intensive dosing schedule required for optimal results in anti-VEGF therapy. Currently, Iluvien is approved by the FDA for the treatment of DME.

\section{Next-generation anti-VEGF-A drugs}

Brolucizumab. Brolucizumab (Novartis Pharmaceuticals, Basel, Switzerland) is a humanized single-chain fragment variable binding to VEGF-A and interfering with activation of VEGF receptor 1 and 2 on endothelial cells. A 6-mg dose of brolucizumab delivers a molar dose which is about 11 and 22 times higher than aflibercept $2 \mathrm{mg}$ and ranibizumab $0.5 \mathrm{mg}$, respectively. In addition, the low molecular weight and high concentration gradient between the vitreous and the retina may increase drug distribution to the target site of action, supporting effective control of anatomical disease activity. The drug has already been shown to be promising for the treatment of neovascularization associated with wet age-related macular degeneration in the HAWK and HARRIER clinical trials ${ }^{43}$. Instead, in regard to DME, a phase 3, multi-center, double-masked clinical trial of this agent is ongoing to evaluate the efficacy and safety of brolucizumab in treatment of adult patients with visual disturbance due to DME in comparison with the administration of aflibercept ${ }^{44}$. The results will be available in the next few years.

Abicipar pegol. Abicipar pegol (Allergan Inc.) belongs to a novel class of small proteins that contain engineered ankyrin repeat domain(s) and bind to target proteins with high specificity and affinity. It is an antagonist of VEGF-A characterized by small size, high potency, and long intravitreal half-life. Results from the phase 2 study showed that abicipar pegol, injected every 8 or 12 weeks in patients affected by DME, offered the functional and anatomical effects with less frequent injections compared with ranibizumab over a 28 -week period ${ }^{45}$.

Angiopoietin combination drugs. Together with VEGF-A, angiopoietin-2 (Ang-2) is considered a key factor in DME pathogenesis. Ang-2 is an antagonist of the Tie2 receptor tyrosine kinase on endothelial cells, counteracting vessel stabilization maintained through Ang-1-dependent Tie2 activation. The excess of Ang-2 and VEGF in the retinal tissues promotes vessel destabilization, vascular leakage, and neovascularization. Ang-2 is also involved in inflammatory pathways such as lymphocyte recruitment ${ }^{46-49}$. Different drugs targeting Ang-2, including RO6867461, a humanized full-length bispecific IgG1 antibody that selectively neutralizes VEGF-A and Ang-2, are in development. A phase III, double-masked, multicenter, randomized study is ongoing to evaluate the efficacy, safety, pharmacokinetics, and optimal treatment frequency of RO6867461 administered by intravitreal injection at 8-week intervals ${ }^{50}$.

Conbercept (KH902). Since its approval in China in 2013, conbercept has been used there for the treatment of neovascular age-related macular degeneration and other retinal vascular diseases, including $\mathrm{DME}^{51,52}$. However, it has not yet reached the market in other countries, although, given its excellent safety and efficacy profile, it has gained worldwide attention as a promising option. It is a recombinant fusion protein composed of the second IgG domain of VEGFR1 and the third and fourth domains of VEGFR2 to the constant region $(\mathrm{Fc})$ of human IgG1. The structure is similar to that of aflibercept; however, conbercept has a VEGFR2 kinase insert domain receptor (KDR) Ig-like region 4 (KDRd4) that can improve the threedimensional structure and increase dimer formation efficiency, thereby increasing the binding capacity of conbercept for VEGF. In vitro experiments have shown that binding of conbercept to VEGF is at least 30 times higher than that of ranibizumab and bevacizumab, achieving the same therapeutic effects but with a lower dose $\mathrm{e}^{53-55}$.

In patients with DME, the FRONTIER ${ }^{56}$ and SAILING $^{57}$ studies showed improvements in visual acuity and corresponding decreases in retinal thickness on optical coherence tomography. More trials on DME are in the planning stages.

\section{Combination drugs}

OPT-302. OPT-302 (Opthea Limited, South Yarra, Victoria, Australia) binds to VEGF receptor 2 and 3, neutralizing the activity of VEGF-C and -D. A combined use of OPT-302 with the currently available anti-VEGF-A therapy may be responsible for a true total VEGF inhibition. A phase $1 \mathrm{~b}$ dose escalation study to evaluate OPT-302 in combination with aflibercept showed good results in vision improvement and reductions in retinal swelling ${ }^{58}$. A phase 2 a randomized controlled clinical study with OPT-302 is ongoing ${ }^{58}$. 
ALG-1001. ALG-1001 (Allegro Ophthalmics, San Juan Capistrano, CA, USA) is a first-in-class integrin peptide therapy. The molecule is able to bind specific integrin receptor sites and works by affecting multiple angiogenic pathways and inflammation. ALG-1001 showed promising results in the phase IIb clinical trial that evaluated it as a sequential therapy or in combination with bevacizumab in patients with $\mathrm{DME}^{59,60}$.

\section{Suprachoroidal corticosteroid}

Promising technologies for drug delivery currently under investigation include refillable surgical intravitreal implants, encapsulated cell technology, and suprachoroidal drug delivery ${ }^{61}$. A phase 1 and 2 exploratory clinical trial examined suprachoroidal triamcinolone acetonide with and without intravitreal aflibercept, demonstrating increased efficacy and durability with the investigational drug ${ }^{62}$. Used together with intravitreal aflibercept, suprachoroidal triamcinolone acetonide was generally well tolerated, and no treatment-related serious adverse events were reported in the TYBEE trial through the 24-week evaluation period $^{63}$.

\section{Management of macular edema: retinal vein occlusion}

ME is the main cause of the deterioration of visual acuity in $\mathrm{RVO}^{64}$. Actually, the first-line therapy in the treatment of ME secondary to RVO is represented by the intravitreal antiVEGF injections of ranibizumab and aflibercept $t^{65,66}$. Moreover, intravitreal corticosteroid agents, such as triamcinolone and dexamethasone implant, have been evaluated ${ }^{67}$ and are currently considered valid therapeutic options in RVO treatment because of their anti-inflammatory, anti-angiogenic, and anti-edema properties. They are able to improve visual acuity in the short term and have proven especially useful in pseudophakic patients or patients who do not experience significant intraocular pressure elevation with local steroid use. In regard to new therapeutic strategies, Iluvien is not yet approved by the FDA for ME secondary to RVO (see features of Iluvien in the "Iluvien" section above). Furthermore, two phase 3 studies are planned in order to evaluate the effect of brolucizumab in patients with ME secondary to RVO (see features of brolucizumab in the "Brolucizumab" section above) $)^{68,69}$.

\section{Management of macular edema: uveitis}

$\mathrm{ME}$ is the most common cause of vision impairment in patients with uveitis, affecting 20 to $30 \%$ of them ${ }^{3,70,71}$. It is typically associated with intermediate or posterior uveitis or panuveitis and is less frequent in anterior uveitis ${ }^{70,72}$. The treatment of uveitic macular edema (UME) can be challenging because of its relapsing nature and its tendency to persist in many cases despite good control of intraocular inflammation ${ }^{72}$. Owing to a lack of prospective randomized controlled clinical trials, an internationally accepted approach to UME has yet to be established.

Below, we analyze the main treatments currently in use and the new therapeutic options for non-infectious UME. Infectious $\mathrm{UME}$, conversely, is treated with targeted anti-microbial therapy, and anti-inflammatory treatments should be used after the active infection has been totally controlled ${ }^{73}$.

\section{Corticosteroids}

Corticosteroids are the mainstay of UME therapy because of their potent and fast-acting anti-inflammatory properties ${ }^{74}$. However, short-term use is advised because of the harmful local (that is, cataract and intraocular pressure elevation) and systemic side effects ${ }^{75}$.

Topical. When inflammation in either subclinical or mild or UME is associated with anterior uveitis, a topical corticosteroid represents the first-line approach. The dose and duration of therapy depend on the underlying cause and the grade of inflammation, beginning with higher doses to be slowly tapered over time ${ }^{76}$.

Periocular. When inflammation is moderate to severe or UME is unresponsive to a topical approach, corticosteroids are administered through periocular depots. Triamcinolone acetonide and methylprednisolone acetate, administered via transeptal or sub-Tenon injections, are the most commonly employed ${ }^{77-79}$.

Intravitreal. Triamcinolone acetonide (Taioftal ${ }^{\circledR}$, Sooft S.p.a., Montegiorgio, Italy) injection via pars plana has been largely used in UME, and the response has been excellent though brief. It appears to be more effective than periocular triamcinolone but with more side effects ${ }^{80}$.

The fully biodegradable slow-release implant of dexamethasone (Ozurdex) is delivered for a period of 4 months and its safety and efficacy in non-infectious intermediate and posterior uveitis have been shown by the HURON study group and others $^{81-83}$. Some studies reported the use of Ozurdex implant in persistent UME secondary to infectious uveitis after total control of active infection ${ }^{84,85}$.

Retisert (Bausch + Lomb, Rochester, NY, USA) is a non-biodegradable FAc 0.59-mg implant surgically implanted through the pars plana and sutured to the sclera. The MUST trial showed the overall superiority of FAc implant in controlling noninfectious uveitis compared with systemic therapy ${ }^{86}$.

Iluvien is a non-biodegradable depot of 0.19 -mg FAc approved for the treatment of DME. Iluvien is currently in randomized controlled clinical trials for the treatment of non-infectious uveitis $^{87}$.

Systemic. Systemic corticosteroids are effective in treating UME, especially when bilateral, but systemic adverse effects prevent their long-term use. Prednisone is the most commonly used, and dosing and tapering should be individualized to the patient $^{88}$.

\section{Non-biologic immunomodulatory agents}

Non-biologic immunomodulatory drugs are used as a secondline treatment for UME as corticosteroid-sparing agents. There are no randomized controlled trials toward the efficacy of these medications specifically on $\mathrm{UME}^{89}$. Non-biologic immunomodulatory drugs include anti-metabolites (azathioprine, methotrexate, and mycophenolate mofetil), inhibitors of T-cell signaling (cyclosporine A, tacrolimus, and sirolimus), and alkylating agents (cyclophosphamide). 
Azathioprine, methotrexate, and mycophenolate mofetil showed some efficacy in the treatment of UME secondary to different non-infectious uveitis ${ }^{90-94}$.

Cyclosporine A and tacrolimus are both effective in patients with uveitis, but few data exist when referring specifically to $\mathrm{UME}^{95,96}$. Intravitreal sirolimus presents a better safety profile than subcutaneous route with good control of inflammation and improvement of UME, but the results of SAVE studies demonstrated that frequent reinjections are needed ${ }^{97-99}$.

Cyclophosphamide inhibits both RNA transcription and DNA duplication. The SITE cohort study showed good control of inflammation with cyclophosphamide with a non-statistically significant increase in cancer-related mortality rates ${ }^{100}$.

\section{Biologic immunomodulatory agents}

Biologic immunomodulatory agents are humanized antibodies used for recalcitrant UME despite steroidal or traditional immunosuppressive treatments or both. Their main adverse effects include exacerbation of infectious and autoimmune diseases.

Tumor necrosis factor alpha blockers (anti-TNF- $\alpha$ ) inhibit TNF$\alpha$, a pro-inflammatory cytokine considered crucial in the pathogenesis of different uveitis ${ }^{101}$. Adalimumab (Humira; AbbVie Inc., North Chicago, IL, USA) is currently the only systemic non-corticosteroid agent which has been approved by the FDA for the treatment of non-infectious intermediate uveitis, posterior uveitis, or panuveitis in adults and children more than 2 years old. Many studies have shown improvement in macular thickness after systemic adalimumab but not after intravitreal administration $^{101-104}$.

Infliximab (Remicade ${ }^{\circledR}$, Janssen Biotech, Inc., Horsham, PA, USA) is an anti-TNF- $\alpha$ administered intravenously. Like adalimumab, infliximab has shown positive results with systemic delivery and but not with an intravitreal route of administration ${ }^{105,106}$.

Golimumab (Simponi ${ }^{\circledR}$, Janssen Biotech Inc.) is another antiTNF- $\alpha$ whose efficacy in UME has been demonstrated in case reports and small case series. Large control studies are required ${ }^{107,108}$.

Etanercept (Enbrel ${ }^{\circledR}$, Immunex Corporation, Seattle, WA, USA) is a fusion protein that blocks TNF- $\alpha$ and TNF- $\beta$ and has been found to be ineffective for uveitis treatment. Its use has been discouraged in many case series ${ }^{93,109}$.

Tocilizumab (Actemra ${ }^{\circledR}$, Genentech Inc., San Francisco, CA, USA) blocks interleukin-6 (IL-6), a strong pro-inflammatory cytokine. Several studies have demonstrated efficacy in UME refractory to previous treatments in different types of uveitis ${ }^{110,111}$.

Rituximab (Rituxan ${ }^{\circledR}$, Genentech Inc.) targets CD20, which is the differentiation cluster of mature B cells. Multi-centered randomized controlled trials are lacking, but small case series have demonstrated beneficial effects in the treatment of non-infectious uveitis and $\mathrm{UME}^{112,113}$.
Many other molecules-such as abatacept (Orencia ${ }^{\circledR}$, BristolMyers Squibb Company, New York, NY, USA), a T-lymphocyte inhibitor; gevokizumab (XOMA 052, XOMA Corporation, Berkeley, CA, USA), an anti-IL-1 $\beta$; ustekinumab (Stelara, Janssen-Cilag International NV, Beerse, Belgium), an anti-IL-12 and anti-IL-23; and filgotinib (GLPG0634), a janus kinase 1are under investigation in different phase 2 clinical trials with promising results ${ }^{14-120}$.

\section{Conclusions}

ME is a major complication of several vascular and inflammatory retinal diseases and multiple mechanisms are implicated in its development. During the acute phase of $\mathrm{ME}$ development, there is a visual function decline that often is reversible after the resolution of the edema (spontaneous resolution or after treatment). On the other hand, long-standing ME causes irreversible anatomical changes of the retina, leading to a permanent impairment of visual function. For these reasons, ophthalmologists should treat $\mathrm{ME}$ in the early phases of development in order to avoid irreversible damage of visual function.

The treatment of ME changes depending on the causative disease. In the DR, different intravitreal drugs for the treatment of DME, such as anti-VEGF injections (ranibizumab and aflibercept) and intravitreal corticosteroids (Ozurdex and Iluvien), are available. However, despite the strong efficacy achieved with these drugs, a significant proportion of patients with DME do not achieve anatomical or functional improvements. For this reason, new drugs are needed in the treatment of persistent or resistant forms of DME. Some of the drugs described here, especially brolucizumab and abicipar pegol, have been shown to be effective in preliminary studies, and these are probably the ones that have a better chance of soon being approved for the treatment of DME.

Also, for ME secondary to RVO, the therapeutic options are very similar to those for DME. However, Iluvien is not yet FDA-approved for the treatment of ME secondary to RVO.

ME secondary to uveitis is another important complication. In this case, a crucial role is played by corticosteroids (topical, periocular, intravitreal, and systemic) and non-biologic immunomodulatory drugs. However, in several cases, there is no resolution of UME, and the introduction into clinical practice of new biologic agents is an important new therapeutic option. Some of these new drugs (that is, adalimumab) have been approved by the FDA whereas several others are under investigation. Nonetheless, first it will be important to prove the safety and efficacy of these new drugs. Only after that will we have new therapeutic options in the treatment of UME.

\section{Abbreviations}

Ang, angiopoietin; DME, diabetic macular edema; DR, diabetic retinopathy; FAc, fluocinolone acetonide; FDA, US Food and Drug Administration; IL, interleukin; ME, macular edema; RVO, retinal vein occlusion; TNF, tumor necrosis factor; UME, uveitic macular edema; VEGF, vascular endothelial growth factor 


\section{Author contributions}

All of the authors made substantial contributions to the conception, acquisition, and interpretation of data; drafted the work or revised it critically for important intellectual content; gave final approval of the version to be published; and agreed to be accountable for all aspects of the work in ensuring that questions related to the accuracy or integrity of any part of the work are appropriately investigated and resolved.

\section{Grant information}

The author(s) declared that no grants were involved in supporting this work.
1. Yau JW, Rogers SL, Kawasaki R, et al: Global prevalence and major risk factors of diabetic retinopathy. Diabetes Care. 2012; 35(3): 556-64. PubMed Abstract | Publisher Full Text | Free Full Text

2. Rogers S, Mclntosh RL, Cheung N, et al:: The prevalence of retinal vein occlusion: pooled data from population studies from the United States, Europe, Asia, and Australia. Ophthalmology. 2010; 117(2): 313-9.e1. PubMed Abstract | Publisher Full Text | Free Full Text

3. Rothova A, Suttorp-van Schulten MS, Frits Treffers W, et al:: Causes and frequency of blindness in patients with intraocular inflammatory disease. $\mathrm{Br}$ Ophthalmol. 1996; 80(4): 332-6.

PubMed Abstract | Publisher Full Text | Free Full Text

4. Daruich A, Matet A, Moulin A, et al:: Mechanisms of macular edema: Beyond the surface. Prog Retin Eye Res. 2018; 63: 20-68.

PubMed Abstract | Publisher Full Text

5. Kohno $\mathrm{T}$, Ishibashi $\mathrm{T}$, Inomata $\mathrm{H}$, et al.: Experimental macular edema of commotio retinae: preliminary report. Jpn J Ophthalmol. 1983; 27(1): 149-56. PubMed Abstract

6. Yanoff M, Fine BS, Brucker AJ, et al.: Pathology of human cystoid macular edema. Surv Ophthalmol. 1984; 28 Suppl: 505-11.

PubMed Abstract | Publisher Full Text

7. Bradbury MW, Lightman SL: The blood-brain interface. Eye (Lond). 1990; 4(Pt 2): 249-54.

PubMed Abstract | Publisher Full Text

8. Törnquist $P$, Alm A, Bill A: Permeability of ocular vessels and transport across the blood-retinal-barrier. Eye (Lond). 1990; 4(Pt 2): 303-9. PubMed Abstract | Publisher Full Text

9. Fruttiger M: Development of the retinal vasculature. Angiogenesis. 2007; 10(2): $77-88$.

PubMed Abstract | Publisher Full Text

10. Klaassen I, van Noorden CJ, Schlingemann RO: Molecular basis of the inner blood-retinal barrier and its breakdown in diabetic macular edema and other pathological conditions. Prog Retin Eye Res. 2013; 34: 19-48. PubMed Abstract | Publisher Full Text

11. Sorrentino FS, Allkabes M, Salsini G, et al:: The importance of glial cells in the homeostasis of the retinal microenvironment and their pivotal role in the course of diabetic retinopathy. Life Sci. 2016; 162: 54-9. PubMed Abstract | Publisher Full Text

12. Omri S, Omri B, Savoldelli M, et al:: The outer limiting membrane (OLM) revisited: clinical implications. Clin Ophthalmol. 2010; 4: 183-95. PubMed Abstract | Publisher Full Text | Free Full Text

13. Achiron $A$, Lagstein $O$, Glick M, et al.: Quantifying metamorphopsia in patients with diabetic macular oedema and other macular abnormalities. Acta Ophthalmol. 2015; 93(8): e649-e653. PubMed Abstract | Publisher Full Text

14. Munk M, Kiss C, Huf W, et al:: Therapeutic interventions for macular diseases show characteristic effects on near and distance visual function. Retina. 2013 33(9): 1915-22.

PubMed Abstract | Publisher Full Text

15. Otani T, Yamaguchi Y, Kishi S: Correlation between visual acuity and foveal microstructural changes in diabetic macular edema. Retina. 2010; 30(5): 774-80. PubMed Abstract | Publisher Full Text

16. Wakabayashi $\mathrm{T}$, Oshima $\mathrm{Y}$, Fujimoto $\mathrm{H}$, et al.: Foveal microstructure and visual acuity after retinal detachment repair: imaging analysis by Fourier-domain optical coherence tomography. Ophthalmology. 2009; 116(3): 519-28. PubMed Abstract | Publisher Full Text

17. Sun JK, Radwan SH, Soliman AZ, et al:: Neural Retinal Disorganization as a Robust Marker of Visual Acuity in Current and Resolved Diabetic Macular Edema. Diabetes. 2015; 64(7): 2560-70. PubMed Abstract | Publisher Full Text | Free Full Text

18. Sacconi R, Corbelli E, Carnevali A, et al.: Optical coherence tomography angiography in pseudophakic cystoid macular oedema compared to diabetic macular oedema: qualitative and quantitative evaluation of retinal vasculature.
Br J Ophthalmol 2018: 102(12): 1684-90.

PubMed Abstract | Publisher Full Text

19. Gass JD, Blodi BA: Idiopathic juxtafoveolar retinal telangiectasis. Update of classification and follow-up study. Ophthalmology. 1993; 100(10): 1536-46. PubMed Abstract | Publisher Full Text

20. Charbel Issa P, Gillies MC, Chew EY, et al:: Macular telangiectasia type 2. Prog Retin Eye Res. 2013; 34: 49-77. PubMed Abstract | Publisher Full Text | Free Full Text

21. Sacconi R, Freund KB, Yannuzzi LA, et al.: The Expanded Spectrum of Perifoveal Exudative Vascular Anomalous Complex. Am J Ophthalmol. 2017; 184: 137-46. PubMed Abstract | Publisher Full Text

22. Ehlers JP, Rayess $\mathrm{H}$, Steinle N: Topical dorzolamide therapy for taxane-related macular oedema. Eye (Lond). 2013; 27(1): 102-4. PublMed Abstract | Publisher Full Text | Free Full Text

23. Duncan KE, Chang LY, Patronas M: MEK inhibitors: A new class of chemotherapeutic agents with ocular toxicity. Eye (Lond). 2015; 29(8): 1003-12. PubMed Abstract | Publisher Full Text | Free Full Text

24. F Bilge AD, Yaylali SA, Yavuz S, et al.: Bilateral serous macular detachment in a patient with nephrotic syndrome. Retin Cases Brief Rep. 2018; 12(3): 260-2. PubMed Abstract | Publisher Full Text | F1000 Recommendation

25. Sarraf D, Rahimy E, Fawzi AA, et al.: Paracentral acute middle maculopathy: a new variant of acute macular neuroretinopathy associated with retinal capillary ischemia. JAMA Ophthalmol. 2013; 131(10): 1275-87. PubMed Abstract | Publisher Full Text

26. Sacconi R, Baldin G, Carnevali A, et al.: Response of central serous chorioretinopathy evaluated by multimodal retinal imaging. Eye (Lond). 2018; 32(4): 734-42.

PubMed Abstract | Publisher Full Text | Free Full Text

27. Das A, McGuire PG, Rangasamy S: Diabetic Macular Edema: Pathophysiology and Novel Therapeutic Targets. Ophthalmology. 2015; 122(7): 1375-94. PubMed Abstract | Publisher Full Text

28. F Mitchell P, Bandello F, Schmidt-Erfurth U, et al:: The RESTORE study: ranibizumab monotherapy or combined with laser versus laser monotherapy for diabetic macular edema. Ophthalmology. 2011; 118(4): 615-25. PubMed Abstract | Publisher Full Text | F1000 Recommendation

29. F Nguyen QD, Brown DM, Marcus DM, et al:: Ranibizumab for diabetic macular edema: results from 2 phase III randomized trials: RISE and RIDE. Ophthalmology. 2012; 119(4): 789-801.

PubMed Abstract | Publisher Full Text | F1000 Recommendation

30. Brown DM, Nguyen QD, Marcus DM, et al.: Long-term outcomes of ranibizumab therapy for diabetic macular edema: the $36-$ month results from two phase III trials: RISE and RIDE. Ophthalmology. 2013; 120(10): 2013-22.

PubMed Abstract | Publisher Full Text

31. Diabetic Retinopathy Clinical Research Network, Wells JA, Glassman AR, et al. Aflibercept, bevacizumab, or ranibizumab for diabetic macular edema. $N$ Engl Med. 2015; 372(13): 1193-203.

PubMed Abstract | Publisher Full Text | Free Full Text

32. F Heier JS, Korobelnik JF, Brown DM, et al.: Intravitreal Aflibercept for Diabetic Macular Edema: 148-Week Results from the VISTA and VIVID Studies. Ophthalmology. 2016; 123(11): 2376-85. PubMed Abstract | Publisher Full Text | F1000 Recommendation

33. F Cai S, Bressler NM: Aflibercept, bevacizumab or ranibizumab for diabetic macular oedema: recent clinically relevant findings from DRCR.net Protocol T. Curr Opin Ophthalmol. 2017; 28(6): 636-43.

PubMed Abstract | Publisher Full Text | F1000 Recommendation

34. $\mathrm{F}$ de Andrade GC, de Oliveira Dias JR, Maia A, et al.: Intravitreal Ziv-Aflibercept for Diabetic Macular Edema: 48-Week Outcomes. Ophthalmic Surg Lasers Imaging Retina. 2018; 49(4): 245-50.

PubMed Abstract | Publisher Full Text | F1000 Recommendation

35. F Mansour AM, Ashraf M, Charbaji A, et al:: Two-year outcomes of intravitrea 
ziv-aflibercept. Br J Ophthalmol. 2018; 102(10): 1387-90.

PubMed Abstract | Publisher Full Text | F1000 Recommendation

36. F Boyer DS, Yoon YH, Belfort R Jr, et al.: Three-year, randomized, shamcontrolled trial of dexamethasone intravitreal implant in patients with diabetic macular edema. Ophthalmology. 2014; 121(10): 1904-14. PubMed Abstract | Publisher Full Text | F1000 Recommendation

37. Smiddy WE: Economic considerations of macular edema therapies. Ophthalmology. 2011; 118(9): 1827-33.

PubMed Abstract | Publisher Full Text | Free Full Text

38. Lang GE, Berta A, Eldem BM, et al:: Two-year safety and efficacy of ranibizumab $0.5 \mathbf{~ m g}$ in diabetic macular edema: interim analysis of the RESTORE extension study. Ophthalmology. 2013; 120(10): 2004-12.

PubMed Abstract | Publisher Full Text

39. Virgili G, Parravano M, Menchini F, et al:: Cost-effectiveness of treatments for diabetic macular oedema: should we pay more attention to the appraisal and reporting of economic evaluations? Br J Ophthalmol. 2014; 98(4): 421-2. PubMed Abstract | Publisher Full Text

40. F Campochiaro PA, Brown DM, Pearson A, et al:: Sustained delivery fluocinolone acetonide vitreous inserts provide benefit for at least 3 years in patients with diabetic macular edema. Ophthalmology. 2012; 119(10): 2125-32. PubMed Abstract | Publisher Full Text | F1000 Recommendation

41. F Bailey C, Chakravarthy U, Lotery A, et al:: Real-world experience with $0.2 \mu \mathrm{g} / \mathrm{day}$ fluocinolone acetonide intravitreal implant (ILUVIEN) in the United Kingdom. Eye (Lond). 2017; 31(12): 1707-15.

PubMed Abstract | Publisher Full Text | Free Full Text | F1000 Recommendation

42. F Fusi-Rubiano W, Mukherjee C, Lane M, et al:: Treating Diabetic Macular Oedema (DMO): real world UK clinical outcomes for the $0.19 \mathrm{mg}$ Fluocinolone Acetonide intravitreal implant (lluvien ${ }^{\mathrm{TM}}$ ) at 2 years. BMC Ophthalmol. 2018; 18(1): 62 .

PubMed Abstract | Publisher Full Text | Free Full Text | F1000 Recommendation

43. F Dugel PU, Koh A, Ogura Y, et al:: HAWK and HARRIER: Phase 3, Multicenter Randomized, Double-Masked Trials of Brolucizumab for Neovascular AgeRelated Macular Degeneration. Ophthalmology. 2019; pii: S0161-6420(18)33018-5. PubMed Abstract | Publisher Full Text | F1000 Recommendation

44. Novartis Pharmaceuticals: Study of efficacy and safety of Brolucizumab vs. Aflibercept in Patients with visual impairment due to diabetic macular edema (KESTREL). In: ClinicalTrials.gov [cited 2019 Apr 27]. Reference Source

45. Hassan TS: A multicenter, double masked phase 2 clinical trial evaluating abicipar pegol for diabetic macular edema. Paper presented at: American Academy of Ophthalmology Annual Meeting; October 14-18; Chicago, IL, 2016.

46. Aiello LP, Avery RL, Arrigg PG, et al:: Vascular endothelial growth factor in ocular fluid of patients with diabetic retinopathy and other retinal disorders. N Engl J Med. 1994; 331(22): 1480-7.

PubMed Abstract | Publisher Full Text

47. Davis $\mathrm{S}$, Aldrich $\mathrm{TH}$, Jones $\mathrm{PF}$, et al:: Isolation of angiopoietin-1, a ligand for the TIE2 receptor, by secretion-trap expression cloning. Cell. 1996; 87(7): 1161-9. PubMed Abstract | Publisher Full Text

48. Maisonpierre PC, Suri C, Jones PF, et al:: Angiopoietin-2, a natural antagonist for Tie2 that disrupts in vivo angiogenesis. Science. 1997; 277(5322): 55-60. PubMed Abstract | Publisher Full Text

49. Fiedler U, KrissI T, Koidl S, et al.: Angiopoietin-1 and angiopoietin-2 share the same binding domains in the Tie-2 receptor involving the first Ig-like loop and the epidermal growth factor-like repeats. J Biol Chem. 2003; 278(3): 1721-7. PubMed Abstract | Publisher Full Text

50. Hoffmann-La Roche: A Study to Evaluate the Efficacy and Safety of Faricimab (RO6867461) in Participants With Diabetic Macular Edema (YOSEMITE). In: ClinicalTrials.gov [cited 2019 Apr 27].

Reference Source

51. F Xu Y, Rong A, Bi Y, et al: Intravitreal Conbercept Injection with and without Grid Laser Photocoagulation in the Treatment of Diffuse Diabetic Macular Edema in Real-Life Clinical Practice. J Ophthalmol. 2016; 2016: 2143082. PubMed Abstract | Publisher Full Text | Free Full Text | F1000 Recommendation

52. $\mathrm{F} X u \mathrm{Y}, \mathrm{Rong} \mathrm{A}, \mathrm{Xu} \mathrm{W}$, et al:: Comparison of 12-month therapeutic effect of conbercept and ranibizumab for diabetic macular edema: a real-life clinical practice study. BMC Ophthalmol. 2017; 17(1): 158. PubMed Abstract | Publisher Full Text | Free Full Text | F1000 Recommendation

53. Zhang M, Yu D, Yang C, et al.: The pharmacology study of a new recombinant human VEGF receptor-fc fusion protein on experimental choroidal neovascularization. Pharm Res. 2009; 26(1): 204-10. PubMed Abstract | Publisher Full Text

54. Zhang M, Zhang J, Yan M, et al.: Recombinant anti-vascular endothelial growth factor fusion protein efficiently suppresses choridal neovasularization in monkeys. Mol Vis. 2008; 14: 37-49. PubMed Abstract | Free Full Text

55. Wang F, Bai Y, Yu W, et al:: Anti-angiogenic effect of KH902 on retinal neovascularization. Graefes Arch Clin Exp Ophthalmol. 2013; 251(19): 2131-9. PubMed Abstract | Publisher Full Text

56. Chengdu Kanghong Biotech Co: Safety and efficacy by multiple injection of KH902 in patients with diabetic macular edema (DME) (Frontier-1).
In: ClinicalTrials.gov [cited 2019 Jul 15].

Reference Source

57. Chengdu Kanghong Biotech Co: Safety and efficacy study of conbercept in diabetic macular edema (DME) (Sailing). In: ClinicalTrials.gov [cited 2019 Jul 15]. Reference Source

58. Opthea Limited: A Dose Ranging Study of OPT-302 With Aflibercept for Persistent Diabetic Macular Edema. In: ClinicalTrials.gov [cited 2019 Apr 27]. Reference Source

59. Kaiser PK: Topline results from prospective, double-masked, placebo controlled phase $2 \mathrm{~b}$ clinical study evaluating Luminate in patients with diabetic macular edema. Paper presented at: Association for Research in Vision and Ophthalmology Annual Meeting; Washington, DC. 2017.

60. Boyer DS: Human phase 2 clinical studies update. DEL MAR Phase 2B. Paper presented at: Angiogenesis 2017; Miami, FL, 2017.

61. Pearce W, Hsu J, Yeh S: Advances in drug delivery to the posterior segment. Curr Opin Ophthalmol. 2015; 26(3): 233-9.

PubMed Abstract | Publisher Full Text | Free Full Text

62. Wykoff CC: Suprachoroidal triamcinolone acetonide with and without intravitreal aflibercept for diabetic macular edema: Phase 1/2 HULK study. Paper presented at American Academy of Ophthalmology Retina Subspecialty Day; November 10-11, New Orleans, LA. 2017

63. Clearside Biomedical, Inc: Suprachoroidal CLS-TA with intravitreal aflibercept versus aflibercept alone in subject with diabetic macular edema (TYBEE). In: ClinicalTrials.gov [cited 2019 Apr 27]

Reference Source

64. Hayreh SS: Ocular vascular occlusive disorders: natural history of visual outcome. Prog Retin Eye Res. 2014; 41: 1-25. PubMed Abstract | Publisher Full Text | Free Full Text

65. F Holz FG, Roider J, Ogura Y, et al:: VEGF Trap-Eye for macular oedema secondary to central retinal vein occlusion: 6-month results of the phase III GALILEO study. Br J Ophthalmol. 2013; 97(3): 278-84. PubMed Abstract | Publisher Full Text | F1000 Recommendation

66. Boyer D, Heier J, Brown DM, et al.: Vascular endothelial growth factor Trap-Eye for macular edema secondary to central retinal vein occlusion: six-month results of the phase 3 COPERNICUS study. Ophthalmology. 2012; 119(5): 1024-32. PubMed Abstract | Publisher Full Text

67. Haller JA, Bandello F, Belfort R Jr, et al:: Randomized, sham-controlled trial of dexamethasone intravitreal implant in patients with macular edema due to retinal vein occlusion. Ophthalmology. 2010; 117(6): 1134-1146.e3. PubMed Abstract | Publisher Full Text

68. Novartis Pharmaceuticals: Assessing the Efficacy and Safety of Brolucizumab Versus Aflibercept in Patients With Visual Impairment Due to Macular Edema Secondary to Central Retinal Vein Occlusion (RAVEN). In: ClinicalTrials.gov [cited 2019 Apr 27] Reference Source

69. Novartis Pharmaceuticals: Assessing the Efficacy and Safety of Brolucizumab Versus Aflibercept in Patients With Visual Impairment Due to Macular Edema Secondary to Branch Retinal Vein Occlusion (RAPTOR). In: ClinicalTrials.gov [cited 2019 Apr 27].

Reference Source

70. F Cunningham ET, Zierhut M: Uveitic Macular Edema. Ocul Immunol Inflamm. 2018; 26(7): 987-90.

Publisher Full Text | F1000 Recommendation

71. Bodaghi B, Cassoux N, Wechsler B, et al.: Chronic severe uveitis: etiology and visual outcome in 927 patients from a single center. Medicine (Baltimore). 2001; 80(4): 263-70.

PubMed Abstract | Publisher Full Text

72. Preble JM, Foster CS: Uveitic macular edema: A stepladder treatment paradigm. Clinical Investigation. 2015; 5(5): 509-17.

Reference Source

73. $\mathrm{F}$ Koronis $\mathrm{S}$, Stavrakas $\mathrm{P}$, Balidis $\mathrm{M}$, et al:: Update in treatment of uveitic macular edema. Drug Des Devel Ther. 2019; 13: 667-80.

PubMed Abstract | Publisher Full Text | Free Full Text | F1000 Recommendation

74. Babu K, Mahendradas P: Medical management of uveitis - current trends. Indian J Ophthalmol. 2013; 61(6): 277-83.

PubMed Abstract | Publisher Full Text | Free Full Text

75. F Dick AD, Rosenbaum JT, Al-Dhibi HA, et al:: Guidance on Noncorticosteroid Systemic Immunomodulatory Therapy in Noninfectious Uveitis: Fundamentals Of Care for UveitiS (FOCUS) Initiative. Ophthalmology. 2018; 125(5): 757-73. PubMed Abstract | Publisher Full Text | F1000 Recommendation

76. Sheppard JD, Toyos MM, Kempen JH, et al:: Difluprednate $0.05 \%$ versus prednisolone acetate $1 \%$ for endogenous anterior uveitis: a phase III, multicenter, randomized study. Invest Ophthalmol Vis Sci. 2014; 55(5): 2993-3002.

PubMed Abstract | Publisher Full Text | Free Full Text

77. Riordan-Eva P, Lightman S: Orbital floor steroid injections in the treatment of uveitis. Eye (Lond). 1994; 8(Pt 1): 66-9. PubMed Abstract | Publisher Full Text

78. Jennings T, Rusin MM, Tessler HH, et al.: Posterior sub-Tenon's injections of corticosteroids in uveitis patients with cystoid macular edema. Jpn $J$ 
Ophthalmol. 1988; 32(4): 385-91.

PubMed Abstract

79. Yoshikawa K, Kotake S, Ichiishi A, et al.: Posterior sub-Tenon injections of repository corticosteroids in uveitis patients with cystoid macular edema. Jpn J Ophthalmol. 1995; 39: 71-6.

PubMed Abstract

80. Cunningham MA, Edelman JL, Kaushal S: Intravitreal steroids for macular edema: the past, the present, and the future. Surv Ophthalmol. 2008; 53(2): 139-49.

PubMed Abstract | Publisher Full Text

81. Lowder C, Belfort R Jr, Lightman S, et al.: Dexamethasone intravitreal implant for noninfectious intermediate or posterior uveitis. Arch Ophthalmol. 2011; 129(5): $545-53$.

PubMed Abstract | Publisher Full Text

82. Tsang AC, Virgili G, Abtahi M, et al.: Intravitreal Dexamethasone Implant for the Treatment of Macular Edema in Chronic Non-infectious Uveitis. Ocul Immunol Inflamm. 2017; 25(5): 685-692.

PubMed Abstract | Publisher Full Tex

83. Cao JH, Mulvahill M, Zhang L, et al.: Dexamethasone intravitreal implant in the treatment of persistent uveitic macular edema in the absence of active inflammation. Ophthalmology. 2014: 121(10): 1871-6.

PubMed Abstract | Publisher Full Text

84. F Fonollosa A, Llorenç V, Artaraz J, et al:: Safety and Efficacy of Intravitreal Dexamethasone Implants in the Management of Macular Edema Secondary to Infectious Uveitis. Retina. 2016; 36(9): 1778-85. PubMed Abstract | Publisher Full Text | F1000 Recommendation

85. F Agarwal A, Handa S, Aggarwal K, et al:: The Role of Dexamethasone Implan in the Management of Tubercular Uveitis. Ocul Immunol Inflamm. 2018; 26(6): $884-92$

PubMed Abstract | Publisher Full Text | F1000 Recommendation

86. Multicenter Uveitis Steroid Treatment Trial Research Group, Kempen JH, Altaweel MM, et al: The multicenter uveitis steroid treatment trial: rationale, design, and baseline characteristics. Am J Ophthalmol. 2010; 149(4): 550-561.e10.

PubMed Abstract | Publisher Full Text | Free Full Text

87. pSivida Corp: Safety and Efficacy Study of a Fluocinolone Acetonide Intravitreal (FAI) Insert in Subjects With Chronic Non-infectious Posterior Uveitis. In: ClinicalTrials.gov [cited 2019 Apr 27].

Reference Source

88. Jabs DA, Rosenbaum JT, Foster CS, et al: Guidelines for the use of immunosuppressive drugs in patients with ocular inflammatory disorders: recommendations of an expert panel. Am J Ophthalmol. 2000; 130(4): 492-513. PubMed Abstract | Publisher Full Text

89. Tranos PG, Wickremasinghe SS, Stangos NT, et al: Macular edema. Surv Ophthalmol. 2004: 49(5): 470-90.

PubMed Abstract | Publisher Full Text

90. Pacheco PA, Taylor SR, Cuchacovich MT, et al.: Azathioprine in the management of autoimmune uveitis. Ocul Immunol Inflamm. 2008; 16(4): 161-5. PubMed Abstract | Publisher Full Text

91. Taylor SR, Habot-Wilner Z, Pacheco P, et al.: Intraocular methotrexate in the treatment of uveitis and uveitic cystoid macular edema. Ophthalmology. 2009; 116(4): 797-801.

PubMed Abstract | Publisher Full Tex

92. Taylor SR, Banker A, Schlaen A, et al:: Intraocular methotrexate can induce extended remission in some patients in noninfectious uveitis. Retina. 2013; 33(10): 2149-54.

PubMed Abstract | Publisher Full Tex

93. Imrie FR, Dick AD: Biologics in the treatment of uveitis. Curr Opin Ophthalmol 2007; 18(6): 481-6.

PubMed Abstract | Publisher Full Tex

94. Doycheva D, Jägle H, Zierhut M, et al:: Mycophenolic acid in the treatment of birdshot chorioretinopathy: long-term follow-up. Br J Ophthalmol. 2014; 99(1): 87-91.

PubMed Abstract | Publisher Full Text

95. Nussenblatt RB, Palestine AG, Chao CC, et al: Randomized, double-masked study of cyclosporine compared to prednisolone in the treatment of endogenous uveitis. Am J Ophthalmol. 1991; 112(2): 138-46. PubMed Abstract | Publisher Full Text

96. Hogan AC, McAvoy CE, Dick AD, et al:: Long-term efficacy and tolerance of tacrolimus for the treatment of uveitis. Ophthalmology. 2007; 114(5): 1000-6. PubMed Abstract | Publisher Full Text

97. Nguyen QD, Ibrahim MA, Watters A, et al:: Ocular tolerability and efficacy of intravitreal and subconjunctival injections of sirolimus in patients with noninfectious uveitis: primary 6-month results of the SAVE Study. $J$ Ophthalmic Inflamm Infect. 2013; 3(1): 32 . PubMed Abstract | Publisher Full Text | Free Full Text

98. F Nguyen QD, Sadiq MA, Soliman MK, et al:: The Effect of Different Dosing Schedules of Intravitreal Sirolimus, a Mammalian Target of Rapamycin (mTOR) Inhibitor, in the Treatment of Non-Infectious Uveitis (An American Ophthalmological Society Thesis). Trans Am Ophthalmol Soc. 2016; 114: T3. PubMed Abstract | Free Full Text | F1000 Recommendation

99. Buhaescu I, Izzedine H, Covic A: Sirolimus--challenging current perspectives. Ther Drug Monit. 2006; 28(5): 577-84.

PubMed Abstract | Publisher Full Tex
100. Kempen JH, Daniel E, Gangaputra S, et al.: Methods for identifying long-term adverse effects of treatment in patients with eye diseases: the Systemic Immunosuppressive Therapy for Eye Diseases (SITE) Cohort Study. Ophthalmic Epidemiol. 2008; 15(1): 47-55.

PubMed Abstract | Publisher Full Tex

101. Sharma SM, Nestel AR, Lee RW, et al.: Clinical review: Anti-TNFalpha therapies in uveitis: perspective on $\mathbf{5}$ years of clinical experience. Ocul Immunol Inflamm. 2009; 17(6): 403-14.

PubMed Abstract | Publisher Full Text

102. F Díaz-Llopis M, Salom D, Garcia-de-Vicuña C, et al:: Treatment of refractory uveitis with adalimumab: a prospective multicenter study of 131 patients. Ophthalmology. 2012; 119(8): 1575-81. PubMed Abstract | Publisher Full Text | F1000 Recommendation

103. Schaap-Fogler M, Amer R, Friling R, et al.: Anti-TNF- $\alpha$ agents for refractory cystoid macular edema associated with noninfectious uveitis. Graefes Arch Clin Exp Ophthalmol. 2014; 252(4): 633-40.

PubMed Abstract | Publisher Full Text

104. Androudi S, Tsironi E, Kalogeropoulos C, et al:: Intravitreal adalimumab for refractory uveitis-related macular edema. Ophthalmology. 2010; 117(8): 1612-6. PubMed Abstract | Publisher Full Text

105. Farvardin M, Afarid M, Shahrzad S: Long-term effects of intravitreal infliximab for treatment of sight-threatening chronic noninfectious uveitis. $J$ Ocul Pharmacol Ther. 2012; 28(6): 628-31. PubMed Abstract | Publisher Full Text

106. Markomichelakis NN, Theodossiadis PG, Pantelia E, et al:: Infliximab for chronic cystoid macular edema associated with uveitis. Am J Ophthalmol. 2004; 138(4): 648-50.

PubMed Abstract | Publisher Full Text

107. Miserocchi E, Modorati G, Pontikaki I, et al.: Golimumab treatment for complicated uveitis. Clin Exp Rheumatol. 2013; 31(2): 320-1. PubMed Abstract

108. F Miserocchi E, Modorati G, Pontikaki I, et al.: Long-term treatment with golimumab for severe uveitis. Ocul Immunol Inflamm. 2014; 22(2): 90-5. PubMed Abstract | Publisher Full Text | F1000 Recommendation

109. F Constantin T, Foeldvari I, Anton J, et al:: Consensus-based recommendations for the management of uveitis associated with juvenile idiopathic arthritis: the SHARE initiative. Ann Rheum Dis. 2018; 77(8): 1107-1117.

PubMed Abstract | Publisher Full Text | Free Full Text | F1000 Recommendation

110. F Deuter CME, Zierhut M, Igney-Oertel A, et al:: Tocilizumab in Uveitic Macular Edema Refractory to Previous Immunomodulatory Treatment. Ocul Immunol Inflamm. 2017; 25(2): 215-20. Inflamm. 2017; 25(2): 215-20.
PubMed Abstract | Publisher Full Text | F1000 Recommendation

111. F Mesquida M, Molins B, Llorenç V, et al.: Twenty-Four Month Follow-Up of Tocilizumab Therapy for Refractory Uveitis-Related Macular Edema. Retina. 2018; 38(7): 1361-70. PubMed Abstract | Publisher Full Text | F1000 Recommendation

112. Davatchi $F$, Shams $H$, Rezaipoor $M$, et al:: Rituximab in intractable ocular lesions of Behcet's disease; randomized single-blind control study (pilot study). Int J Rheum Dis. 2010; 13(3): 246-52.

PubMed Abstract | Publisher Full Text

113. $\mathrm{F}$ Miserocchi $\mathrm{E}$, Modorati $\mathrm{G}$, Berchicci $\mathrm{L}$, et al:: Long-term treatment with rituximab in severe juvenile idiopathic arthritis-associated uveitis. $\mathrm{Br}$ Ophthalmol. 2016; 100(6): 782-6.

PubMed Abstract | Publisher Full Text | F1000 Recommendation

114. Tappeiner C, Miserocchi E, Bodaghi B, et al:: Abatacept in the treatment of severe, longstanding, and refractory uveitis associated with juvenile idiopathic arthritis. J Rheumatol. 2015; 42(4): 706-11. PubMed Abstract | Publisher Full Text

115. Elhai M, Deslandre CJ, Kahan A: Abatacept for refractory juvenile idiopathic arthritis-associated uveitis: two new cases. Comment on the article by Zulian et al. Arthritis Care Res (Hoboken). 2011; 63(2): 307-8; author reply 308. PubMed Abstract | Publisher Full Text

116. Kenawy N, Cleary G, Mewar D, et al:: Abatacept: a potential therapy in refractory cases of juvenile idiopathic arthritis-associated uveitis. Graefes Arch Clin Exp Ophthalmol. 2011; 249(2): 297-300. PubMed Abstract | Publisher Full Text

117. Oregon Health and Science University: Abatacept in the Treatment of Uveitis. In: ClinicalTrials.gov [cited 2019 Apr 27]. Reference Source

118. F Tugal-Tutkun I, Pavesio C, De Cordoue A, et al.: Use of Gevokizumab in Patients with Behçet's Disease Uveitis: An International, Randomized, DoubleMasked, Placebo-Controlled Study and Open-Label Extension Study. Ocul Immunol Inflamm. 2018; 26(7): 1023-33. PubMed Abstract | Publisher Full Text | F1000 Recommendation

119. National Eye Institute (NEI): Ustekinumab (STELARA) for the Treatment of Active Sight-Threatening Uveitis (STAR Study). In: ClinicalTrials.gov [cited 2019 Apr 27]. Reference Source

120. Gilead Sciences: Efficacy and Safety of Filgotinib in Adults With Active Noninfectious Uveitis (Humboldt). In: ClinicalTrials.gov [cited 2019 Apr 27] Reference Source 


\section{Open Peer Review}

\section{Current Peer Review Status:}

\section{Editorial Note on the Review Process}

Faculty Reviews are review articles written by the prestigious Members of Faculty Opinions. The articles are commissioned and peer reviewed before publication to ensure that the final, published version is comprehensive and accessible. The reviewers who approved the final version are listed with their names and affiliations.

\section{The reviewers who approved this article are:}

\section{Version 1}

\section{Akitaka Tsujikawa}

Department of Ophthalmology and Visual Sciences, Kyoto University Graduate School of Medicine, Kyoto, Japan

Competing Interests: No competing interests were disclosed.

\section{Andrew A. Chang}

1 Sydney Institute of Vision Science, Sydney, NSW, Australia

2 Save Sight Institute, University of Sydney, Sydney, NSW, Australia

Competing Interests: No competing interests were disclosed.

The benefits of publishing with F1000Research:

- Your article is published within days, with no editorial bias

- You can publish traditional articles, null/negative results, case reports, data notes and more

- The peer review process is transparent and collaborative

- Your article is indexed in PubMed after passing peer review

- Dedicated customer support at every stage

For pre-submission enquiries, contact research@f1000.com

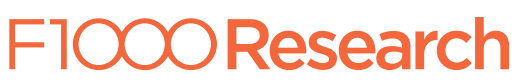

